\title{
Batik Production Village's Adaptation on the Pandemic COVID-19
}

\author{
Ika Rizkiyanti ${ }^{1}$, Bangun I.R. Harsritanto ${ }^{1 *}$, Tia Hetwisari $^{2}$ \\ ${ }^{1}$ Architecture Department, Engineering Faculty, Universitas Diponegoro, Semarang, Indonesia \\ ${ }^{2}$ Ministry of Public Works and Housing, Directorate General Human Settlement, Region Central \\ Java, Semarang, Indonesia
}

\begin{abstract}
The pandemic of covid-19 has affected urban and rural areas in Indonesia. Batik Production Village is a village with most of the population is dedicated their work to batik production. The adaptations were related to strategies in physical designs, health protocols implementations, and social interaction. Indonesia has many batik production villages; however, this study location was Simbang Kulon Village on Pekalongan Resident. The interaction between each strategy also shown that rural area has unique adaptation related to the pandemic. This study consists of literature study and site observations to elaborate the batik production village adaptations against the pandemic. The result showed one of the generic portraits of rural area adaptation during this pandemic in Indonesia.
\end{abstract}

\section{Introduction}

Batik from Indonesia is an art that has been well known since the Majapahit kingdom era and has developed through every generation. Batik has spread widely in Nusantara and become the collective art of Indonesian people (primarily Javanese) from the 18th century until the present. At the beginning of batik creation, it was an entire industry of the Nusantara kingdom. Batik was only made by an internal circle of particular artists and worn by noble societies inside the aristocracy (king's family and their followers) - the batik was initially been designed with dedicated persons, processes, and products. Indonesia's transformation from batik started from the noble family's permit to design and make the product from outside the kingdom wall. This condition made reduplication and a new style of batik that belonged to non-aristocracy families. The Java rulers conditioned those conditions through the era to encourage their citizens on social engagement. The ordinary people become prouder toward their king and bring more attention to the kingdom through their descendants. Authors found that present batik artists and makers have ancestors who also batik artists for the kingdom in the past, so it becomes historical facts and family industries [1]. Pekalongan is one of the cities with a long history for their batik as a cultural asset and creative industry. Pekalongan has become Batik city on the north coast of Java since the 18th century. That fact was supported by the quantity of Batik Central Production that is located in this residence. Each production center has similarities in making the process even though the location was spread all over Pekalongan [2].

* Corresponding author: bangunirh@arsitektur.undip.ac.id 
Near the end of 2019, the world was surprised by a report of the COVID--19 cases on Wuhan, China. Until the present, the case of COVID-19 has continued to become everyday consumption of media all over the world [3-5]. At March 2020, World Health Organization (WHO) officially stated that novel Corona Virus Disease 19 (nCOVID-19) as global pandemic as the fact that almost all part of the world has infected by COVID-19 [6]. On the 29th of May 2021. It was about 222 countries reported having 170,256,454 positive COVID- 19, 152,148,821 cured and 3,540,426 persons died by this pandemic [7]. On the same day, Pekalongan residence reported 617 suspects inside the area and four suspects outside Pekalongan [8]. That condition is worse as the "mudik Labaran 2021" as annual mass mobility from a metropolitan urban area to Pekalongan [9][10].

With the condition mentioned above, these research aims are to investigate the condition and report the adaptation of Batik Production Village on pandemic covid-19. The location of our research is Simbang Kulon Batik Village in Pekalongan city, Indonesia. In this research, we found that vulnerability of rural area related to covid 19 cases; however, the socialization about new normal adaptation is not massive enough and may cause clusters of covid 19.

\section{Method}

This study uses a literature study and direct site observation. The data is obtained from the site and descriptively analyzed with the literature of health protocol, Simbang Kulon plan, and batik village-related literature (Fig. 1). The data such as location, photo, and layout were collected by several visits during the pandemic in 2020 and 2021, while literature study and data mining were taken from the internet. The data analysis was performed by triangulation of theory, site observation, and online data. Therefore, some data will be eliminated from the process, and some will be strengthened with a new fact to support argumentations.

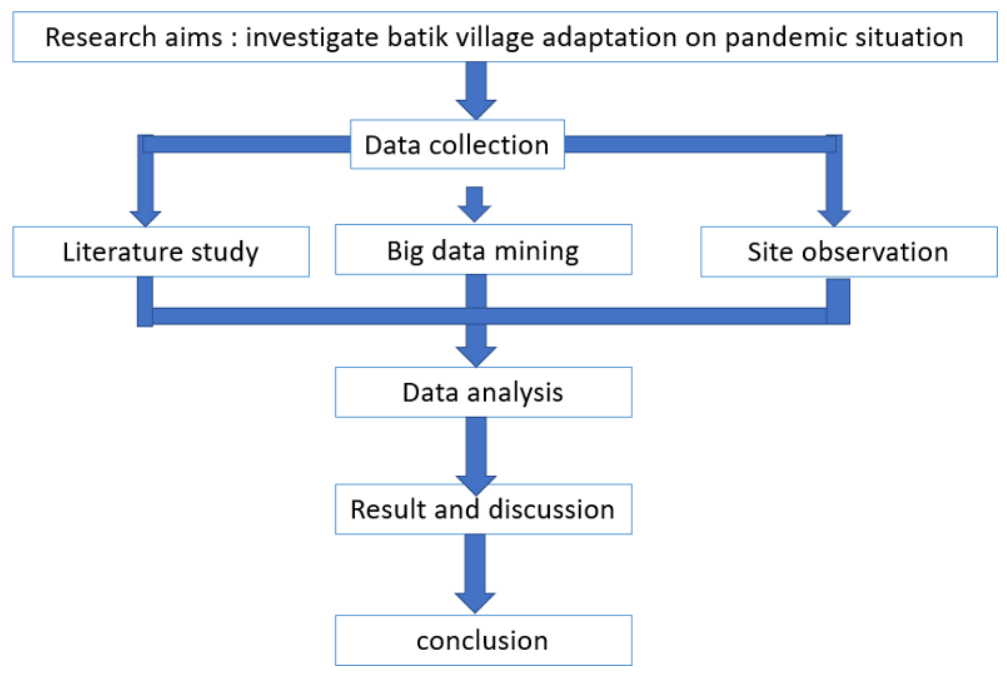

Figure 1. Research Diagram. 


\section{Material and Discussion}

Simbang Kulon village is part of the Pekalongan residence in Central Java Province, Indonesia. Simbang Kulon is located on Kecamatan Buaran on the north side of Pekalongan and has become one of Batik villages with most villagers working in the batik industry (figure 2). This village has many medium densities $\left(7309 \mathrm{man} / \mathrm{km}^{2}\right)$ and of the house of 618 of them are part of the batik industry (see figure 3 )

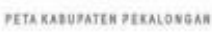

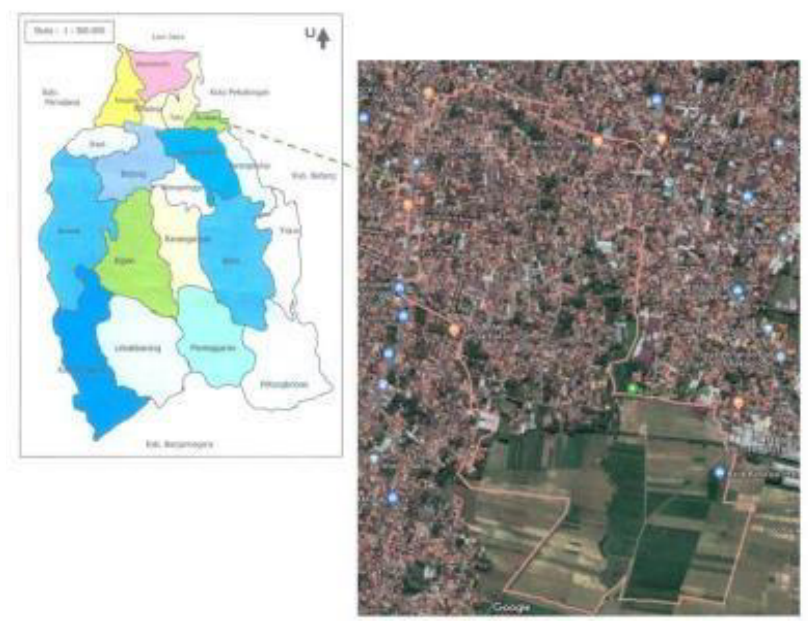

Figure 2. Location of Simbang Kulon village [11].

\begin{tabular}{|c|c|c|c|c|}
\hline \multirow{2}{*}{\multicolumn{2}{|c|}{ Desa }} & $\begin{array}{c}\text { Luas } \\
\text { Daerah } \\
\mathrm{Km}^{2}\end{array}$ & $\begin{array}{l}\text { Jumlah } \\
\text { Penduduk }\end{array}$ & $\begin{array}{c}\text { Kepadatan } \\
\text { Penduduk } \\
\text { Per } \mathrm{Km}^{2}\end{array}$ \\
\hline & & [2] & [3] & [4] \\
\hline 001 & Coprayan & 1.11 & 3.916 & 3.527 \\
\hline 002 & Sapugarut & 0.48 & 3.375 & 7.031 \\
\hline 003 & Wonoyoso & 0.64 & 4.436 & 6.931 \\
\hline 004 & Bligo & 0.65 & 4.121 & 6.340 \\
\hline 005 & Pakumbulan & 1.21 & 4.117 & 3.402 \\
\hline 006 & Watusalam & 1.58 & 4.199 & 2.657 \\
\hline 007 & Simbang Wetan & 0.69 & 4.805 & 6.963 \\
\hline 008 & Simbang Kulon & 1.21 & 8.844 & 7.309 \\
\hline 009 & Kertijayan & 0.91 & 6.339 & 6.965 \\
\hline 010 & Paweden & 1.06 & 3.313 & 3.125 \\
\hline & Jumlah & 9.54 & 47.465 & 4. 975 \\
\hline
\end{tabular}

\begin{tabular}{|c|c|c|c|c|c|}
\hline \multicolumn{2}{|r|}{ Des a } & \multicolumn{2}{|c|}{ Kecil } & \multicolumn{2}{|c|}{ Kerajinan RT } \\
\hline & & Usaha & $\begin{array}{c}\text { Tenaga } \\
\text { Kerja }\end{array}$ & Usaha & $\begin{array}{c}\text { Tenaga } \\
\text { Kerja }\end{array}$ \\
\hline & [1] & {$[2]$} & [3] & [4] & {$[5]$} \\
\hline 001 & Coprayan & 26 & 212 & 148 & 312 \\
\hline 002 & Sapugarut & 22 & 129 & 42 & 94 \\
\hline 003 & Wonoyoso & 66 & 442 & 122 & 327 \\
\hline 004 & Bligo & 31 & 254 & 51 & 118 \\
\hline 005 & Pakumbulan & 46 & 347 & 67 & 182 \\
\hline 006 & Watusalam & 23 & 188 & 58 & 166 \\
\hline 007 & Simbang Wetan & 98 & 512 & 216 & 639 \\
\hline 008 & Simbang Kulon & 176 & 874 & 442 & 862 \\
\hline 009 & Kertijayan & 158 & 948 & 711 & 1.009 \\
\hline 010 & Paweden & 21 & 119 & 122 & 168 \\
\hline & Jumlah & 667 & 4.025 & 1.979 & 3.877 \\
\hline
\end{tabular}

Figure 3. Simbang Kulon density (left) and batik production (right) [11].

As we know, that medium density of people is vulnerable to the spread of COVID-19. The batik workers must wear medical mask protection during their social activities. The mask can prevent respiratory problems spread by viruses or bacteria, including COVID-19 [13]. The ministry of health also mandates the usage of masks to protect workers not only for disease prevention but also for protecting our respiratory system from chemical material often used in the batik industry [14]. As shown in figure 4, most workers are not wearing medical masks. This situation is noted to be a vulnerable part of this rural society toward 
COVID-19. Some people feel uncomfortable by the mask and resulting in challenging breathing conditions [13].

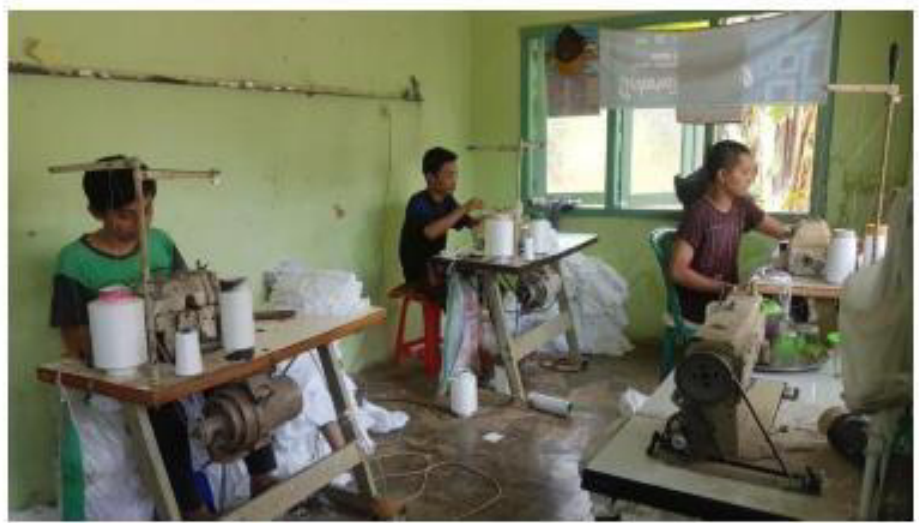

Figure 4. Situation on batik production (weaving process).

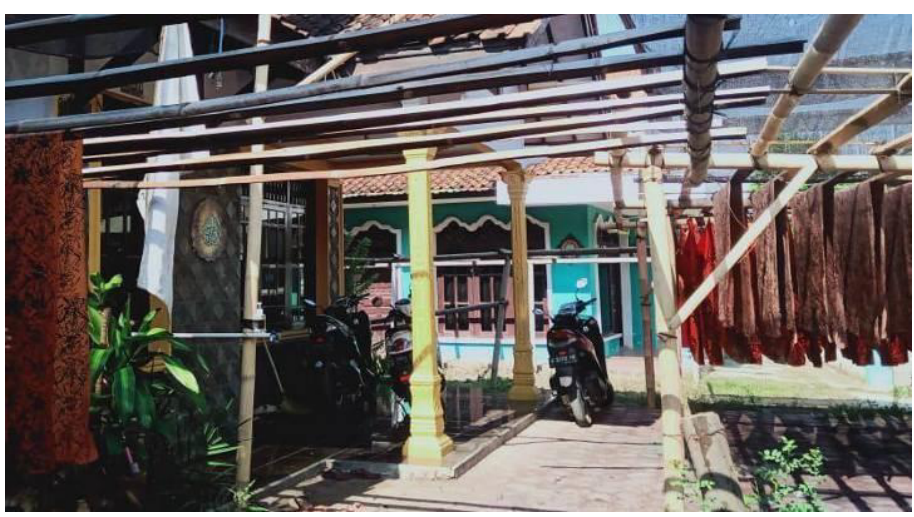

Figure 5. Handwash facility outside of house.

Regarding the education facilities of the Simbang Kulon people, most of the people in Kecamatan Buaran attend school in Simbang Kulon village. Furthermore, with the highest medical facilitators in their village, the workers shall understand and follow the health protocol promoted to cut the COVID-19 spreading (figure 6). Some informational forum of a pandemic spreading prevention shall be held frequently to give more awareness to the people, such as daily sports and exercise to increase the body immunity [15], psychological consultation [16], school curriculum [17] in every event, especially in religion activity [18].

In the annual event of Mudik Labaran (hometown visits), the government has made limitations and restrictions for all regions [19]. However, the people insist on doing mudik under the pandemic situation with many tricks [20]. The case of hometown visits that rise the COVID-19 suspects does not just happen to Simbang Kulon. It also happened in China on Imlek or Lunar New Year event [21] and America on thanksgiving situations [22][23].

With the vulnerability facts of Batik village conditions, after the mudik, Labaran 2021 predicted a significant increase in the number of COVID-19 cases in all rural areas of Indonesia. Simbang Kulan in Pekalongan will also get the share of suspects since many Jakarta, Depok, Tangerang, Bekasi (Jabodetabek) are coming from this village. Some media warned the local government to respond quickly to the spreadings by activating the hospital expansion and working the hours extend [25]. 


\begin{tabular}{|c|c|c|c|c|c|c|c|}
\hline & \multirow{2}{*}{ Desa } & \multicolumn{2}{|c|}{ Sekolah } & \multicolumn{3}{|c|}{ Murid } & \multirow{2}{*}{ Guru } \\
\hline & & Negeri & Swasta & L & $P$ & $\mathrm{Jml}$ & \\
\hline & [1] & {$[2]$} & [3] & [4] & [5] & [6] & [7] \\
\hline 001 & Coprayan & 0 & 0 & 0 & 0 & 0 & 0 \\
\hline 002 & Sapugarut & 0 & 0 & 0 & 0 & 0 & 0 \\
\hline 003 & Wonoyoso & 0 & 1 & 174 & 221 & 395 & 33 \\
\hline 004 & Bligo & 0 & 0 & 0 & 0 & 0 & 0 \\
\hline 005 & Pakumbulan & 0 & 0 & 0 & 0 & 0 & 0 \\
\hline 006 & Watusalam & 0 & 1 & 62 & 68 & 130 & 15 \\
\hline 007 & Simbang Wetan & 0 & 0 & 0 & 0 & 0 & 0 \\
\hline 008 & Simbang Kulon & 0 & 2 & 497 & 474 & 971 & 39 \\
\hline 009 & Kertijayan & 0 & 0 & 0 & 0 & 0 & 0 \\
\hline 010 & Paweden & 0 & 0 & 0 & 0 & 0 & 0 \\
\hline & Jumlah & 0 & 4 & 733 & 763 & 1.496 & 87 \\
\hline & 2018 & 0 & 4 & 688 & 769 & 1.457 & 89 \\
\hline & 2017 & 0 & 4 & 675 & 731 & 1.406 & 77 \\
\hline
\end{tabular}

\begin{tabular}{lcccccc}
\hline \hline \multirow{2}{*}{ Desa } & \multicolumn{1}{c}{ Dokter Bidan Bides } & $\begin{array}{c}\text { Para } \\
\text { medis }\end{array}$ & $\begin{array}{c}\text { Dukun } \\
\text { Bay }\end{array}$ & Jumlah \\
\hline$[1]$ & {$[2]$} & {$[3]$} & {$[4]$} & {$[5]$} & {$[6]$} & {$[7]$} \\
\hline 001 Coprayan & 0 & 1 & 1 & 4 & 1 & 7 \\
002 Sapugarut & 3 & 1 & 1 & 5 & 0 & 8 \\
003 Wonoyoso & 0 & 1 & 1 & 2 & 2 & 6 \\
004 Bligo & 1 & 0 & 1 & 2 & 1 & 5 \\
005 Pakumbulan & 0 & 0 & 1 & 1 & 2 & 4 \\
006 Watusalam & 0 & 0 & 1 & 4 & 0 & 5 \\
007 Simbang Wetan & 2 & 1 & 1 & 1 & 2 & 7 \\
008 Simbang Kulon & 2 & 1 & 1 & 2 & 3 & 9 \\
009 Kertijayan & 2 & 1 & 1 & 1 & 1 & 6 \\
010 Paweden & 0 & 0 & 1 & 0 & 2 & 4 \\
\hline \hline & 10 & 6 & 10 & 22 & 14 & 61 \\
\hline
\end{tabular}

Figure 6. Facility on Simbang Kulon (left: school, right: medical).

From the recent data from the internet, Pekalongan also had prepared the quarantine building for the COVID-19 patients who came from outside areas. The 26 rooms of the Pekalongan training center were being reserved to quarantine the hometown traveler who was detected positively infected [26]. Learned from other countries lessons toward homecoming situation, this facility is not enough to prevent the batik village from COVID19 in physical design. However, economically, digital marketing and product differentiation may save the batik village from a financial crisis [27][28].

From every aspect of Simbang Kulon physical design, working situations, society's improvement, and economic innovations, the traditional primary village is very vulnerable to COVID-19 spreading. The people need to be warned more often as a healthy society while building a friendlier environment for batik industries during this pandemic.

\section{Conclusion}

Health protocol awareness for pandemic situations plays a vital role in preventing the COVID-19 from spreading's. However, rural and remote areas are not ready enough for the implementation of health protocols. Some societies said, "no COVID-19 on the village" is real, but with mudik/hometown events, the jargon is obsolete and changed. Traditional batik village-like Simbang Kulon is still performing the industries as a pre-pandemic situation. The workers are not wearing masks, working in a small distance, with inadequate washing hand (sanitation) facilities made this rural area vulnerable to COVID-19 suspect and rapid infections.

Massive promotion of health protocol to build COVID-19 ready society and more sanitize-healthy equipment shall be developed in this area. Furthermore, innovation in batik production-distribution-marketing is also being suggested to avoid the further impact of the COVID-19 pandemic. 


\section{Acknowledgments}

This research was financially supported by The Faculty of Engineering, Diponegoro

University, Indonesia through Strategic Research Grant 2021

\section{References}

1. Ulum, Ihyaul. "Batik dan Kontribusinya terhadap Perekonomian Nasional." Bestari, no. 42, 2009.

2. I. Rizkiyanti and B. I. R. Harsritanto, "Pola Pemanfaatan Ruang pada Rumah Pengrajin Batik di Desa Simbang Kulon," Arsir, vol. 4, no. 2, p. 65, Dec. 2020, doi: 10.32502/arsir.v4i2.2423.

3. Daga, M. K., Kumar, N., Aarthi, J., Mawari, G., Garg, S., \& Rohatgi, I. From SARSCoV to Coronavirus Disease 2019 (COVID-19)-A Brief Review. Journal of Advanced Research in Medicine (2019)

4. Woznitza, N., Hare, S. S., \& Nair, A. Covid-19 pandemic: Summary of current and emerging issues for radiographers. Work, 20. (2019).

5. Guo, Y.-R., Cao, Q.-D., Hong, Z.-S., Tan, Y.-Y., Chen, S.-D., Jin, H.-J., Tan, K.-S., Wang, D.-Y., \& Yan, Y. The Origin, Transmission and Clinical Therapies on Coronavirus Disease 2019 (COVID-19) Outbreak - An Update on the Status. Military Medical Research, 7(11). (2020).

6. Cucinotta, D., \& Vanelli, M. WHO declares COVID-19 a pandemic. Acta Bio-Medica: Atenei Parmensis,91(1), 157-160. (2020).

7. https://www.worldometers.info/coronavirus accesed 29 mei 2021

8. https://corona.pekalongankab.go.id/ accesed 29 mei 2021

9. https://www.solopos.com/mudik-ke-pekalongan-warga-jakarta-positif-coronameninggal-dunia-1056196 accessed 29 mei 2021

10. https://www.medcom.id/nasional/daerah/8N0jzodk-14-556-orang-memasuki-kawasanpekalongan accesed 29 mei 2021

11. maps.Google.com accesed 30 may 2021

12. Kecamatan Buaran dalam angka 2020, accesed 30 may 2021

13. Lia Rosa Veronika Sinaga, Seri Asnawati Munthe, Henny Arwina Bangun .SOSIALISASI PERILAKU CUCI TANGAN PAKAI SABUN DI DESA SAWO SEBAGAI - BENTUK KEPEDULIAN TERHADAP MASYARAKAT DITENGAH MEWABAHNYA VIRUS COVID-19. Vol 1 No 2 : JURNAL ABDIMAS MUTIARA.19 - 28 (2020)

14. https://jdih.kemenkeu.go.id/fulltext/2012/152 PMK.010 2012Per.HTM accesed 29 mei 2021

15. Ricky Fernando, Muspita Muspita, M. Fransazeli Makorohim. Membudayakan Olahraga Pada Masyarakat di Masa Pandemi di Desa Sialang Sakti, Kec. Dayun Kab. Siak. Community Education Engagement Journal. Vol 22 no 2. 79-85 (2021) https://doi.org/10.25299/ceej.v2i2.6673

16. Fadhlina Rozzaqya (2021) Urgensi Konseling Krisis dalam Menghadapi Pandemi Covid-19 Di Indonesia. Prosiding Seminar Bimbingan dan Konseling. Mengukuhkan Eksistensi Peran BK Pasca Pandemi Covid-19 di Berbagai Setting Pendidikan. 136-143

17. http://conference.um.ac.id/index.php/bk2/article/view/91/94

18. F S. Sulaeman and S. Supriadi, "Peningkatan Pengetahuan Masyarakat Desa Jelantik Dalam Menghadapi Pandemi Corona Virus Diseases-19 (Covid-19)," Pengabdian. Pemberdayaan. Pelatihan, vol. 1, no. 1 (2020)

doi: 10.33394/jpu.v1i1.2548. 
19. Nurul Hidayah Nasution, Hasni Yaturramadhan, Widya Angraini, Silvia Yolandi. SOSIALISASI DALAM UPAYA PENCEGAHAN PENYEBARAN COVID 19 DI AREA MESJID AL-MAHMUDAH. Jurnal Pengabdian Masyarakat Aufa (JPMA). Vol 2 No 3 6-13 (2020)

20. anggara, sahya and Afiah, Salamatul and Farida, Ai Siti and Muslim, Jaliludin. Inovasi kebijakan publik tentang pencegahan dan penanggulangan corona virus disease 19 (Covid-19) di Jawa Barat (2020) http://digilib.uinsgd.ac.id/30850/

21. M. Mutharuddin and B. D. Hartanto, "Pengaruh Pendemi Covid-19 Terhadap Persepsi Masyarakat Jabodetabek Untuk Melakukan Perjalanan Mudik," JPTD, vol. 22, no. 2, pp. 107-114 (2021)

doi: $10.25104 /$ jptd.v22i2.1657

22. X. Liu, D. Zhang, T. Sun, X. Li, and H. Zhang, "Containing COVID-19 in rural and remote areas: experiences from China," Journal of Travel Medicine, vol. 27, no. 3 (2020)

doi: $10.1093 / \mathrm{jtm} / \mathrm{taaa} 060$.A

23. D. Dandachi, R. Reece, E. W. Wang, T. Nelson, C. Rojas. Moreno, and D. M. Shoemaker, "Treating COVID 19 in Rural America," The Journal of Rural Health, vol. 37, no. 1, pp. 205-206, Sep. 2020, doi: 10.1111/jrh.12457.

24. J. T. Mueller, K. McConnell, P. B. Burow, K. Pofahl, A. A. Merdjanoff, and J. Farrell, "Impacts of the COVID-19 pandemic on rural America," Proc Natl Acad Sci USA, vol. 118, no. 1, p. 2019378118 , Dec. 2020, doi: 10.1073/pnas. 2019378118

25. https://lokadata.id/artikel/lonjakan-covid-19-makin-terasa-pemerintah-perlu-segerabersiap accesed 30 may 2021

26. https://jateng.inews.id/berita/pemkot-pekalongan-siapkan-rumah-karantina-bagipemudik-terdeteksi-positif-covid-19/2 accessed 30 may 2021

27. Mohammad Rosyada, Anah Wigiawati. STRATEGI SURVIVAL UMKM BATIK TULIS PEKALONGAN DI TENGAH PANDEMI COVID-19 (STUDI KASUS PADA "BATIK PESISIR" PEKALONGAN). Jurnal Bisnis dan Kajian Strategi Manajemen. Vol 4 no.2 (2020)

28. A. Priyono, A. Moin, and V. N. A. O. Putri, "Identifying Digital Transformation Paths in the Business Model of SMEs during the COVID-19 Pandemic," Journal of Open Innovation: Technology, Market, and Complexity, vol. 6, no. 4, p. 104, Oct. 2020. 